\title{
PENGARUH PENGENDALIAN PH TERHADAP PEMBENTUKAN ETANOL DAN PERGESERAN PRODUK ASIDOGENESA DARI FERMENTASI LIMBAH CAIR INDUSTRI MINYAK SAWIT \\ (The Influence of pH Control on Ethanol and Switch of Acidogenic Products Formation from Palm Oil Mill Effluent)
}

\author{
David Andrio $^{1 *}$, Mindriany Syafila ${ }^{2}$, Marisa Handajani ${ }^{2}$ dan Dessy Natalia ${ }^{3}$ \\ ${ }^{1}$ Program Doktor Teknik Lingkungan, Fakultas Teknik Sipil dan Lingkungan, \\ Institut Teknologi Bandung. Jln. Ganesha No. 10, Bandung, 40132. \\ ${ }^{2}$ Kelompok Keahlian Rekayasa Air dan Limbah Cair, Fakultas Teknik Sipil dan Lingkungan, \\ Institut Teknologi Bandung. Jln. Ganesha No. 10, Bandung, 40132. \\ ${ }^{3}$ Kelompok Keahlian Biokimia, Fakultas Matematika dan Ilmu Pengetahuan \\ Institut Teknologi Bandung. Jln. Ganesha No. 10, Bandung, 40132.
}

*Penulis korespondensi. No Tel: 081268531099. Email: davidandrio2009@gmail.com.

Diterima: 9 September 2014

Disetujui: 23 Februari 2015

\begin{abstract}
Abstrak
Limbah cair industri minyak sawit memiliki potensi sebagai substrat pembentukan etanol. Pemanfaatan kultur campuran dalam pembentukan etanol memiliki keuntungan karena tidak memerlukan sterilisasi substrat, namun akan dihasilkan berbagai produk samping dan sebaliknya pada Saccharomyces cerevisiae. Penelitian ini bertujuan untuk mempelajari pengaruh pengaturan $\mathrm{pH}$ terhadap pembentukan etanol dan produk asidogenesa. Rancangan penelitian terdiri dari reaktor bakteri anaerob dan ragi dengan perlakuan pengendalian $\mathrm{pH}$ pada rentang 6-6,5 dan tanpa pengendalian $\mathrm{pH}$ dengan $\mathrm{pH}$ awal fermentasi 6-6,5. Hasil penelitian menunjukkan Degree Acidification (DA), Total Asam Volatil (TAV) dan etanol tertinggi berurutan sebesar 0,32;808,03 mg/L dan 24,03 $\mathrm{mg} / \mathrm{L}$ pada reaktor bakteri dengan pengendalian $\mathrm{pH} ; 0,23 ; 522,43 \mathrm{mg} / \mathrm{L}$ dan $23,12 \mathrm{mg} / \mathrm{L}$ pada reaktor tanpa pengendalian $\mathrm{pH} ; 0,25 ; 775,78 \mathrm{mg} / \mathrm{L}$ dan $34,11 \mathrm{mg} / \mathrm{L}$ pada reaktor ragi dengan pengendalian $\mathrm{pH}$ dan 0,$32 ; 866,71 \mathrm{mg} / \mathrm{L}$ dan $29,17 \mathrm{mg} / \mathrm{L}$ pada reaktor ragi tanpa pengendalian $\mathrm{pH}$. Pengendalian $\mathrm{pH}$ fermentasi meningkatkan pembentukan produk asetil-KoA dari $4,35 \%$ menjadi $7,34 \%$ pada reaktor bakteri dan dari $17,92 \%$ menjadi $18,78 \%$ pada reaktor ragi dan tidak berpengaruh terhadap pembentukan etanol.
\end{abstract}

Kata kunci: asam lemak volatil, bakteri kultur campuran anaerob, degree acidification, etanol, keasaman, Saccharomyces cerevisiae.

\section{Abstract}

Palm oil mill effluent has potention for substrate to ethanol formation. Utilization of anaerobic mixed culture bacteria to form ethanol has advantages i.e not requiring sterilization of the substrate and vice versa in Saccharomyces cerevisiae, but resulting side products. The aims of this research are to study effect of controlling $\mathrm{pH}$ on ethanol formation and acidogenic products. Design experiment consisted of anaerobic bacteria and yeast reactor with the pH control in the range of $\mathrm{pH} 6$ - 6.5 and initial $\mathrm{pH}$ 6-6.5 for without $\mathrm{pH}$ control treatment. The results showed the highest Degree Acidification (DA), Total Volatile Fatty Acid (TVFA) and ethanol are 0.32; $808.03 \mathrm{mg} / \mathrm{L}$ and $24.03 \mathrm{mg} / \mathrm{L} \mathrm{for}$ bacteria reactor with $\mathrm{pH}$ control; $0.23 ; 522.43 \mathrm{mg} / \mathrm{L}$ and $23.12 \mathrm{mg} / \mathrm{L}$ for bacteria reactor without $\mathrm{pH}$ control; 0.25 ; $775.78 \mathrm{mg} / \mathrm{L}$ and $34.11 \mathrm{mg} / \mathrm{L}$ for yeast reactor with $\mathrm{pH}$ control and $0.32 ; 866.71 \mathrm{mg} / \mathrm{L}$ and $29.17 \mathrm{mg} / \mathrm{L}$ for yeast reactor without $\mathrm{pH}$ control. Controlling $\mathrm{pH}$ increasing acetyl-CoA product formation from $4.35 \%$ to $7.34 \%$ for bacteria reactor and from $17.92 \%$ to $18.78 \%$ for yeast one and not affect to rising ethanol formation.

Keywords: acidity, degree acidification, ethanol volatile fatty acids, mixed culture anaerobic bacteria, Saccharomyces cerevisiae.

\section{PENDAHULUAN}

Peningkatan kebutuhan sumber energi dan semakin terbatasnya cadangan bahan bakar fosil menuntut pengembangan bahan bakar alternatif yang ramah lingkungan dan terbarukan. Salah satunya adalah etanol yang merupakan bahan bakar yang banyak diteliti (Wu dkk, 2007; Murdiyatmo, 2006; Demirbas, 2005). Umumnya, bahan baku pembuatan etanol di Indonesia berasal dari ubi kayu dan gula yang masih tergolong sebagai bahan pangan manusia (Murdiyatmo, 2006). Hal ini akan menimbulkan persaingan antara konsumsi sebagai bahan pangan dan atau sebagai bahan baku produksi etanol yang akan berdampak pada peningkatan nilai jual bioetanol. Salah satu alternatif untuk mengatasi permasalahan tersebut adalah dengan pemanfaatan limbah cair organik 


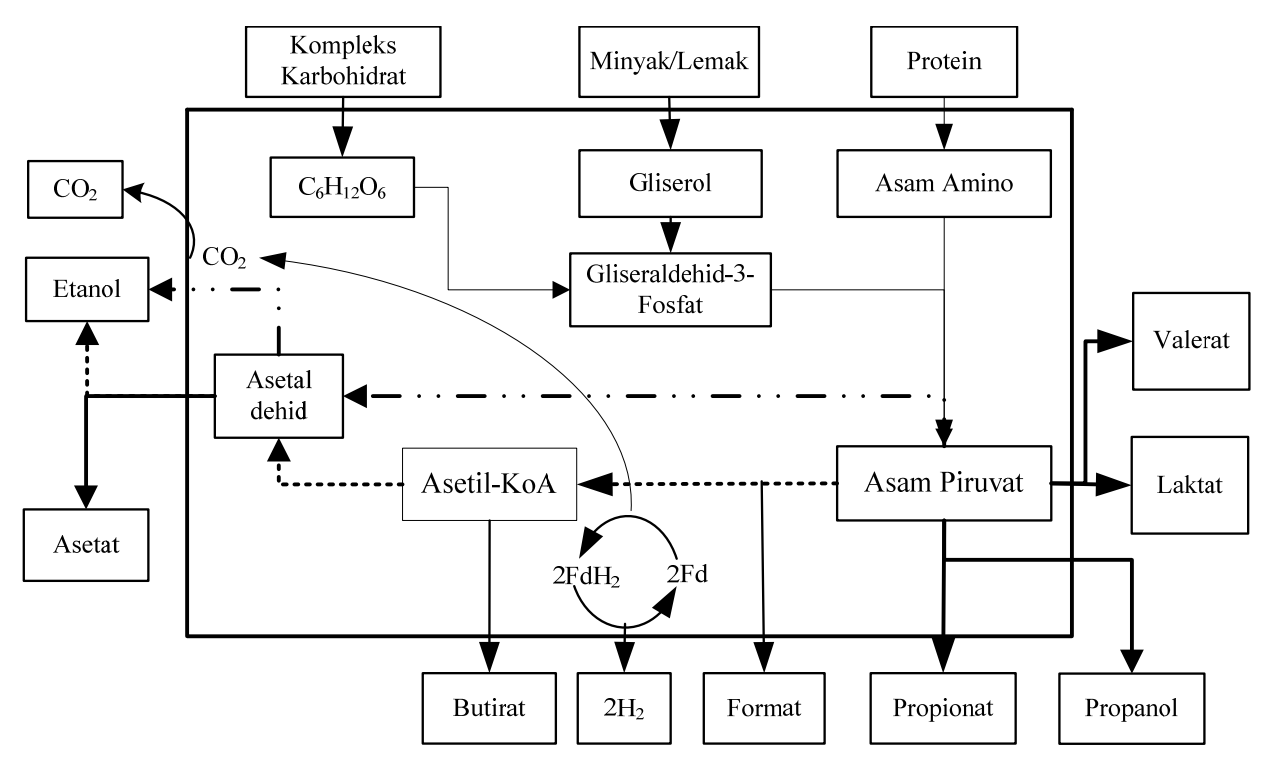

Gambar 1. Jalur metabolik asidogenesa dari glukosa dan substrat senyawa organik kompleks (modifikasi Temudo dkk., 2007; Tang dkk., 2005; Kosaric dan Sukan 2001; Ren dkk., 1997).

......... : Jalur pembentukan etanol oleh bakteri kultur campuran anaerob

-..-. : Jalur pembentukan etanol oleh organisme yang memiliki enzim pyruvate decarboxylase

(PDC)

yang mengandung Chemical Oxygen Demand (COD) di atas $4.000 \mathrm{mg} / \mathrm{L}$ melalui proses anaerob (Grady dkk., 1999). Posisi Indonesia sebagai penghasil minyak mentah sawit, karet alam dan kakao bertutur-turut nomor satu, dua dan tiga di dunia (Anonim, 2011; Mohammadi dkk., 2010; Ardhana dan Fleet, 2003) memungkinkan pemanfaatan limbah cair tersebut. Kandungan senyawa organik yang tinggi dalam limbah cair sawit berkisar 50.000-70.000 mg COD/L (Poh dan Chong, 2009; Ahmad dkk., 2003; Syafila dkk., 1998), kakao 50.000-100.000 mg COD/L (Syafila dkk, 2010) dan karet alam 3.500-14.000 mg COD/L (Mohammadi dkk, 2010; Tekasakul dan Tekasakul, 2006) sangat memungkinkan untuk dimanfaatkan sebagai alternatif substrat produksi etanol.

Sebagai produk antara pada tahap asidogenesa, etanol terbentuk melalui reduksi asetaldehid dengan bantuan enzim alkohol dehidrogenase. Mikro organisme penghasil etanol dapat dibedakan dari jalur konversi asam piruvat menjadi asetildehid (Gambar 1). Jalur konversi asam piruvat menjadi asetil-KoA dan selanjutnya ke asetaldehid digunakan oleh bakteri kultur campuran anaerob. Bakteri ini terdiri dari berbagai konsorsium bakteri yang dapat memanfaatkan limbah cair sebagai substrat. Selain etanol, jalur ini akan menghasilkan berbagai produk samping berupa asam lemak volatil dan non volatil sehingga akan mempengaruhi produksi etanol (Andrio dkk., 2012; Syafila dkk., 2010; Ren dkk., 2007; Ren dkk., 2006; Wang dkk., 2006; Ren dkk., 1997).

Sementara itu, jalur konversi langsung asam piruvat menjadi asetaldehid digunakan oleh mikro organisme yang memiliki enzim piruvat dekarboksilase seperti Zymomonas mobilis, Sarcina ventriculi, Erwinia amylovora, bakteri penghasil asam asetat dan Saccharomyces cerevisiae (Roger dkk, 2006; Kosaric dan Sukan, 2001). Jalur ini membutuhkan sterilisasi substrat untuk mencegah kontaminasi dan pengolahan pendahuluan untuk substrat yang sulit terbiodegradasi (Lin dkk., 2011; Chotineeranat dkk., 2010; Zhao dkk., 2009; Yamashita dkk, 2008; Demirbas, 2005; Lewis dkk, 2005).

Seperti yang telah disebutkan sebelumnya, etanol yang dihasilkan oleh kultur campuran bakteri anaerob akan diikuti dengan berbagai produk samping, sehingga untuk meningkatkan efisiensi pembentukan etanol maka pembentukan produk samping harus diminimalkan. Secara umum, $\mathrm{pH}$ medium tidak hanya mempengaruhi pertumbuhan dan laju fermentasi tetapi juga mempengaruhi yield produk (Zhu dan Yang, 2004). Beberapa hasil penelitian menyatakan kondisi optimal pembentukan etanol oleh bakteri kultur campuran anaerob pada substrat molase dan atau glukosa terjadi dalam rentang $\mathrm{pH}$ 4-5 (Wang dkk., 2006; Wang dkk., 2006 ; Yu dan Fang, 2003; Ren dkk., 1997), rentang pH 5-5,5 (Ren dkk., 2007; Ren dkk., 2006; Han dkk., 2003) dan pada rentang pH 6-8 (Lu dkk, 2008; Temudo dkk, 2007; Fang dan Liu, 2002). Meskipun demikian, pada kompleks substrat yang mengandung pati, protein dan minyak/lemak belum banyak diteliti sehingga perlu diteliti lebih lanjut pengaruh pengendalian $\mathrm{pH}$ terhadap pembentukan etanol dan distribusi produk asidogenesa. 
Tujuan penelitian ini adalah untuk mempelajari pengaruh pengendalian $\mathrm{pH}$ terhadap pembentukan dan pergeseran produk asidogenesa dari biodegradasi limbah cair agro industri sebagai upaya pemanfaatan limbah cair yang mengandung senyawa organik konsentrasi tinggi. Dari penelitian ini akan diketahui pengaruh pengendalian $\mathrm{pH}$ terhadap efektivitas pembentukan etanol dan pergeseran pembentukan produk samping. Efektivitas produksi etanol oleh bakteri kultur campuran anaerob akan dibandingkan dengan produksi etanol oleh ragi S. cerevisiae.

\section{METODE PENELITIAN}

\section{Biomassa dan Limbah Cair}

Bibit bakteri anaerob berasal dari lumpur kolam pengolahan limbah cair industri minyak sawit dan rumen sapi dengan perbandingan 1:1 $(\% \mathrm{v} / \mathrm{v})$. Sebagai pembanding produksi etanol, ragi S. cerevisiae diperoleh dari Pusat Antar Universitas Institut Teknologi Bandung, Indonesia. Pengayaan bakteri dilakukan dalam media menurut Yenigun dkk. (1996), terdiri dari glukosa (20 g/L) dan trace mineral yang terdiri dari $448 \mathrm{mg} / \mathrm{L} \mathrm{K} \mathrm{HPO}_{4} ; 2,256$ $\mathrm{mg} / \mathrm{L} \mathrm{NH}_{4} \mathrm{HCO}_{3} ; 85 \mathrm{mg} / \mathrm{L} \mathrm{MgCl} 2.6 \mathrm{H}_{2} \mathrm{O} ; 4,83 \mathrm{mg} / \mathrm{L}$ $\mathrm{FeCl}_{3} .6 \mathrm{H}_{2} \mathrm{O} ; 0,444 \mathrm{mg} / \mathrm{L} \mathrm{NiCl} .6 \mathrm{H}_{2} \mathrm{O} ; 0,402 \mathrm{mg} / \mathrm{L}$ $\mathrm{CoCl}_{2} \cdot 6 \mathrm{H}_{2} \mathrm{O}$ dan $0,036 \mathrm{mg} / \mathrm{L}\left(\mathrm{NH}_{4}\right)_{6} \mathrm{Mo}_{7} \mathrm{O}_{24} \cdot 4 \mathrm{H}_{2} \mathrm{O}$. Untuk media pertumbuhan ragi mengandung $30 \mathrm{~g} / \mathrm{L}$ dekstros, $5 \mathrm{~g} / \mathrm{L}$ ekstrak ragi dan $3 \mathrm{~g} / \mathrm{L}$ pepton (Shen dkk., 2010). Penelitian ini menggunakan limbah cair organik artifisial dengan karakteristik yang merepresentasikan limbah cair industri minyak sawit yang terdiri dari pati $2.000 \mathrm{mg} / \mathrm{L}$; pepton $5.100 \mathrm{mg} / \mathrm{L}$; minyak $6.390 \mathrm{mg} / \mathrm{L}$ dan trace mineral seperti $3,95 \quad \mathrm{mg} / \mathrm{L} \quad \mathrm{NH}_{4} \mathrm{HCO}_{3} ; \quad 0,06743 \quad \mathrm{mg} / \mathrm{L}$ $\mathrm{K}_{2} \mathrm{HPO}_{4} ; 0,5661 \mathrm{mg} / \mathrm{L} \quad \mathrm{FeCl}_{3} 6 \mathrm{H}_{2} \mathrm{O} ; 2,466 \mathrm{mg} / \mathrm{L}$ $\mathrm{MgCl}_{2} \quad 6 \mathrm{H}_{2} \mathrm{O} ; 1,721 \mathrm{mg} / \mathrm{L} \quad \mathrm{CaCl}_{2} \cdot 6 \mathrm{H}_{2} \mathrm{O} ; 0,1571$ $\mathrm{mg} / \mathrm{L} \mathrm{NaHCO}_{3} ; 0,0140 \mathrm{mg} / \mathrm{L} \mathrm{MnCl}{ }_{2} 6 \mathrm{H}_{2} \mathrm{O} ; 0,0056$ $\mathrm{mg} / \mathrm{L} \quad \mathrm{ZnCl}_{2} \quad 6 \mathrm{H}_{2} \mathrm{O} ; \quad 0,0047 \mathrm{mg} / \mathrm{L} \quad \mathrm{CuCl}_{2} \quad 6 \mathrm{H}_{2} \mathrm{O}$; $0,0020 \quad \mathrm{mg} / \mathrm{L} \quad \mathrm{CoCl}_{2} \cdot 6 \mathrm{H}_{2} \mathrm{O} ; \quad 0,00078 \quad \mathrm{mg} / \mathrm{L}$ $\mathrm{CrCl}_{2} \cdot 6 \mathrm{H}_{2} \mathrm{O}$ dan $0,00003 \mathrm{mg} / \mathrm{L} \mathrm{CdCl}{ }_{2} 6 \mathrm{H}_{2} \mathrm{O}$ (Wong and Chin, 1985 dalam Ahmad, 2001). Aklimatisasi biomassa dilakukan secara bertahap dengan meningkatkan konsentrasi limbah cari artifisial secara bertahap dimulai dari 0, 30, 50 dan $100 \%$ (v/v). Semua bahan kimia yang digunakan Pro Analytic Grade, Merck.

\section{Operasional Reaktor}

Bioreaktor (Gambar 2) yang digunakan berupa erlemeyer dengan volume kerja $1 \mathrm{~L}$ dan kecepatan shaker $100 \mathrm{rpm}, 25{ }^{\circ} \mathrm{C}$. Reaktor diisi dengan campuran media yang terdiri dari 20\% (v/v) biomassa dan $80 \%$ (v/v) substrat. Penelitian dilaku-

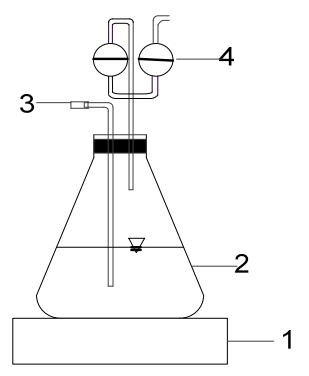

Gambar 2. Rangkaian reaktor penelitian. (1) shaker, (2) erlenmeyer flask; (3) titik sampling; (4) leher angsa (air sealer).

kan secara batch dengan dua kali ulangan. Rancangan penelitian terdiri dari reaktor dengan pengendalian $\mathrm{pH}$ dalam rentang 6-6,5 (R1, reaktor bakteri dengan pengendalian $\mathrm{pH}$ dan $\mathrm{R} 3$, reaktor ragi dengan pengendalian $\mathrm{pH}$ ) dan tanpa pengendalian $\mathrm{pH}$ (R2, reaktor bakteri tanpa pengendalian $\mathrm{pH}$ dan $\mathrm{R} 4$, reaktor ragi tanpa pengendalian $\mathrm{pH}$ ). $\mathrm{pH}$ awal seluruh reaktor diatur dalam rentang 6-6,5 dan pengaturan $\mathrm{pH} \mathrm{R} 1$ dan $\mathrm{R} 3$ dilakukan setiap 12 jam setelah pengambilan sampel dengan menginjeksikan larutan $2 \mathrm{M} \mathrm{HCl}$ dan atau $2 \mathrm{M} \mathrm{NaOH}$ ke dalam reaktor. Untuk menciptakan kondisi anaerob dilakukan flushing $\mathrm{N}_{2}$ selama 10 menit. Pengamatan fermentasi dilakukan setiap 12 jam dengan parameter yang diamati COD total dan terlarut, Total Asam Volatil (TAV), Asam-asam Volatil (AV) dan non volatil serta etanol.

\section{Metoda Analisis}

Preparasi sampel untuk analisis COD terlarut, TAV, AV dan etanol dilakukan dengan sentrifuge sampel pada kecepatan $6.000 \mathrm{rpm}$ selama 15 menit dan disaring dengan Whatman no. 42. Analisis individu asam volatil dan non volatil menggunakan High-Performance Liquid Chromatographic (HPLC) mengikuti metoda de Sa dkk (2011). Preparasi sampel dengan menyaring sampel menggunakan nyllon acrodisc syringe ukuran 0,22 $\mu \mathrm{m}$ milipore dan dilanjutkan proses ultrasonifikasi selama 10 menit untuk menghilangkan gas.

HPLC yang digunakan tipe Hitachi interface D-7000 HSM dilengkapi dengan UV-Vis detektor (Hitachi L-7400) dan pompa (Hitachi L-7100). Kolom analitik Aminex HPX-87H (300 mm x 7,8 $\mathrm{mm}$ dan ukuran partikel $9 \mu \mathrm{m})$. Fase gerak terdiri dari $5 \mathrm{mM} \mathrm{H}_{2} \mathrm{SO}_{4}$, metanol dan aquabides. Kondisi operasi pada $55{ }^{\circ} \mathrm{C}$, laju alir $1 \mathrm{~mL} / \mathrm{menit}$, volume injeksi $1 \mu \mathrm{L}$. Deteksi asam laktat, format, asetat, propionat, butirat dan valerat mengunakan UV-Vis pada panjang gelombang $210 \mathrm{~nm}$. Pembuatan kurva kalibrasi standar pada konsentrasi 10, 30, 50, 70 dan $100 \mathrm{mM}$.

Analisis etanol menggunakan Gas Chromatography Shimadzhu 17-A, kolom analitik 
DB-Wax (prophylene glycol) $(30 \mathrm{~m} \times 0,25 \mathrm{~mm})$. Preparasi sampel dilakukan dengan mengekstrak campuran $1 \mathrm{~mL}$ sampel $+0,5 \mathrm{~mL}$ paraxylene. Selanjutnya pelarut dipisahkan dan $1 \mu \mathrm{L}$ sampel diijeksi. Kondisi operasi pada suhu kolom $80{ }^{\circ} \mathrm{C}$, suhu injektor dan detektor $250{ }^{\circ} \mathrm{C}$, tekanan $\mathrm{N}_{2} 68$ $\mathrm{kpa}$, laju alir nitrogen $0,7 \mathrm{~L} / \mathrm{min}$, split ratio 1:20. Kurva kalibrasi standar etanol dibuat pada konsentrasi 25, 50, 100 dan 200 ppm. Analisis konsentrasi COD (total dan terlarut) dan VSS menggunakan Standard Methods for the Examination of Water and Wastewater berurutan 5220C, SM 2540E dan SM 5560.

\section{Perhitungan}

Analisis data fermentasi dengan menghitung (Bengtsson dkk, 2008), Degree acidification pada kondisi batch,

$$
\mathrm{DA}=\frac{\text { Total Asam volatil }}{\text { COD terlarut influen }} \frac{[\mathrm{mgCOD} / \mathrm{L}]}{[\mathrm{mgCOD} / \mathrm{L}]}
$$

Total asam volatil $(\mathrm{TAV})=($ format + asetat + propionat + butirat + valerat, $\mathrm{mg} / \mathrm{L}$ )

Yield produk, $\mathrm{Y}_{p}=$

$$
\frac{[\text { Produk outlet }]-[\text { Produk Inlet }]}{[\text { COD terlarut in }- \text { produk in })-[\text { COD terlarut out-produk out }]} \frac{[\mathrm{mg} \mathrm{COD} / \mathrm{L}]}{[\mathrm{mgCOD} / \mathrm{L}]}
$$

Laju pembentukan produk asidogenesa $=$ (produk maksimum - produk influen)/waktu

Analisis neraca massa digunakan untuk mengetahui pengaruh pengaturan $\mathrm{pH}$ terhadap jalur pembentukan produk asidogenesa. Perhitungan dilakukan dengan mengonversi setiap produk asidogenesa terhadap equivalen COD terlarut teoritis menggunakan persamaan menurut Bengtsson, dkk (2009):

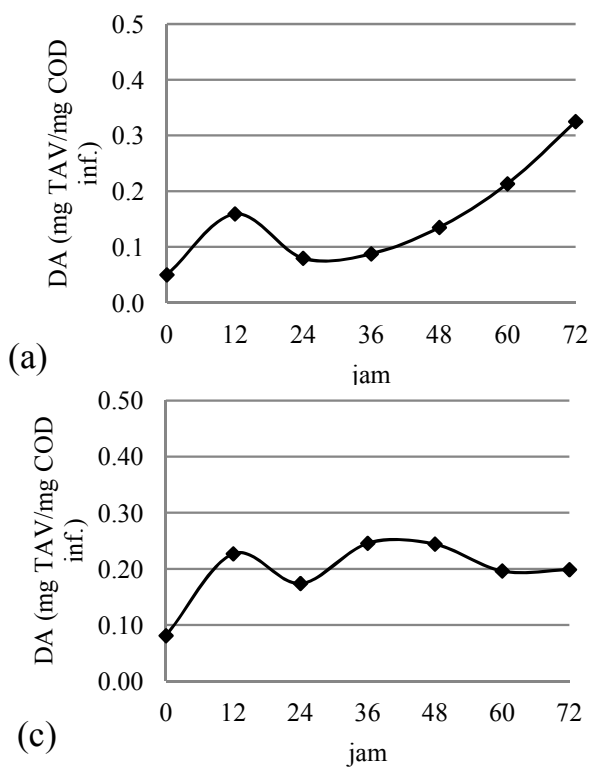

$$
\begin{aligned}
& \mathrm{COD}_{\text {teoritical }}=8 \cdot(4 \mathrm{x}+\mathrm{y}-2 \mathrm{z}) /(12 \mathrm{x}+\mathrm{y}+16 \mathrm{z}) \mathrm{gCOD} \cdot \mathrm{g}^{-1} \\
& \mathrm{CxHyOz} \\
& \text { Di mana } x=\mathrm{C} ; y=\mathrm{H} \text { dan } z=\mathrm{O} .
\end{aligned}
$$

\section{HASIL DAN PEMBAHASAN}

\section{Asidogenesa Limbah Cair Organik Konsentrasi Tinggi}

Proses biodegradasi asidogenesa ditandai dengan pembentukan asam-asam volatil, non volatil dan alkohol serta penurunan $\mathrm{pH}$ media. Hasil penelitian disajikan dalam Gambar 3 yang menunjukkan pembentukan total asam lemak volatil (degree acidification/DA) pada reaktor bakteri baik dengan dan tanpa pengendalian $\mathrm{pH}$ mencapai puncak pada jam ke-72. DA tertinggi R1 sebesar 0,32 dengan produk utama berupa format, asetat, propionat dan valerat berturut-turut sebesar 87,15; 338,57; 85,57 dan 296,74 mg/L. Pada R2, DA tertinggi sebesar 0,23 dengan produk utama berupa format, asetat, propionat dan valerat berurutan sebesar 98,76; 88,09; 99,53 dan 236,05 $\mathrm{mg} / \mathrm{L}$. Sementara itu, DA tertinggi pada R3 sebesar 0,25 dengan produk utama fermentasi berupa format, asetat, propionat dan valerat berurutan sebesar 105,55; 340,50; 126,72 dan 203,01 mg/L dan 108,$32 ; 348,68 ; 90,95$ dan $244,31 \mathrm{mg} / \mathrm{L}$ pada R4 dengan DA tertinggi sebesar 0,27.

\section{Pengaruh Pengendalian pH Terhadap Jalur Pembentukan Etanol}

Pembentukan etanol pada R1 mencapai puncak pada jam ke-60 sebesar 24,03 $\mathrm{mg} / \mathrm{L}$ dan pada jam ke-72 sebesar 23,12 mg/L pada R2. Pada reaktor teroksidasi menjadi asetat atau tereduksi membentuk etanol. Pada jam ke-48 dan 60, asetaldehid
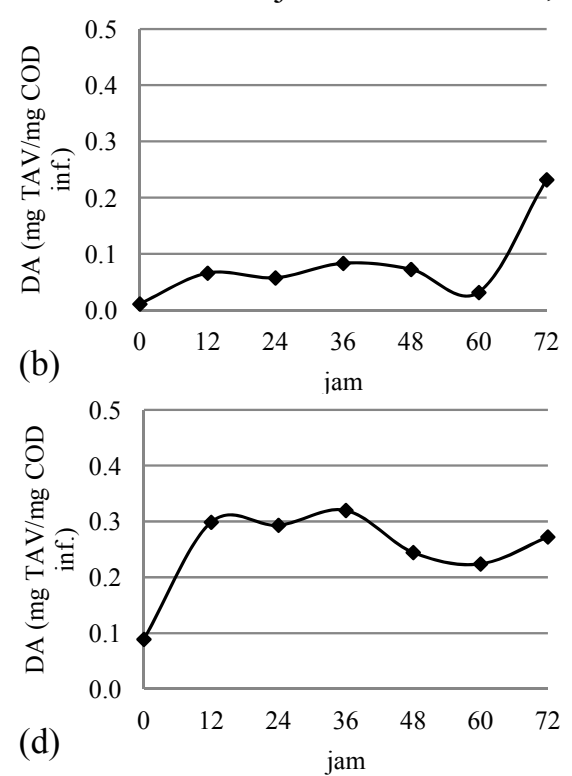

Gambar 3. Pengaruh pengendalian $\mathrm{pH}$ terhadap degree acidification/DA. (a) R1; (b) R2; (c) R3 dan (d) R4. 


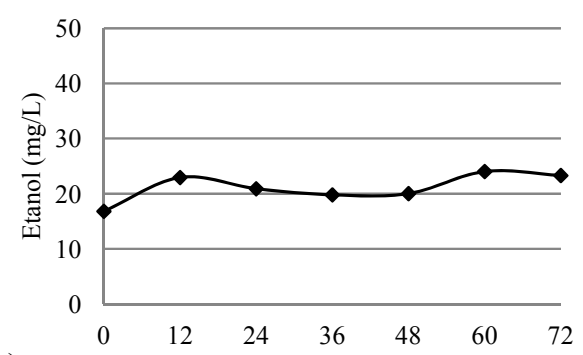

(a)

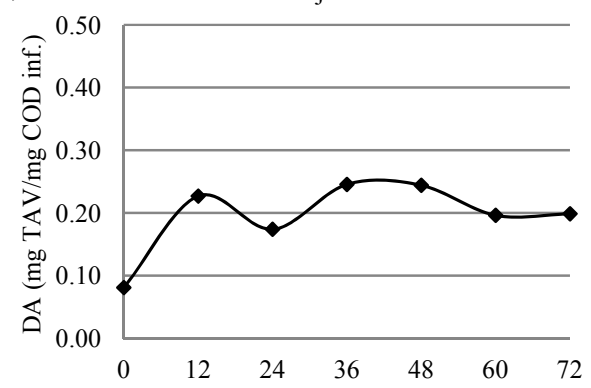

(c)

jam (b)
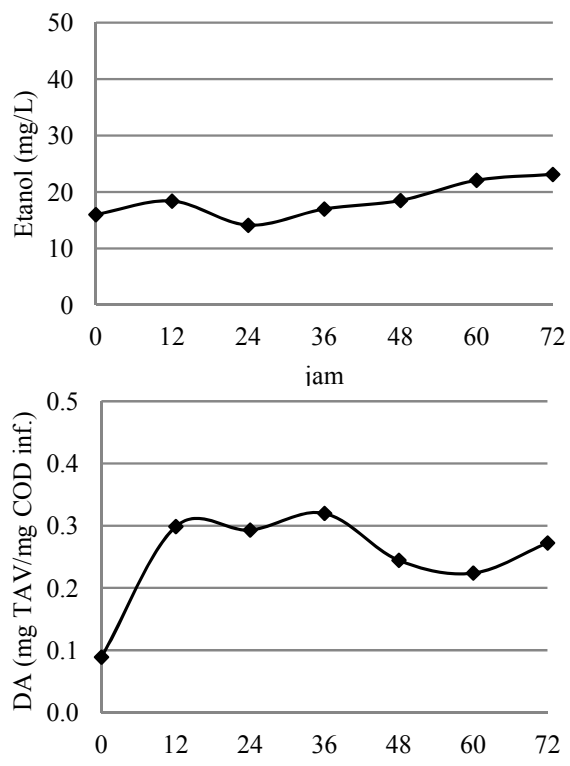

(d)

jam

Gambar 4. Pengaruh pengendalian pH terhadap pembentukan etanol. (a). R1; (b). R2; (c). R3 dan (d). R4.

Tabel 1. Produk asidogenesa yang terbentuk saat etanol tertinggi.

\begin{tabular}{lrrrr}
\hline \multicolumn{1}{c}{ Parameter } & Reaktor 1 & \multicolumn{1}{c}{ Reaktor 2 } & \multicolumn{1}{c}{ Reaktor 3 } & Reaktor 4 \\
\hline Yield ethanol & 0,03 & 0,02 & 0,02 & 0,08 \\
Degree acidification & 0,21 & 0,23 & 0,20 & 0,22 \\
& Produk metabolisme $(\mathrm{mg} / \mathrm{L})$ & & \\
Total asam lemak volatil & 739,73 & 522,43 & 651,70 & 665,66 \\
Asam laktat $\left(\mathrm{CH}_{3} \mathrm{CHOHCOOH}\right)$ & 577,12 & 899,49 & $1.055,38$ & $1.083,37$ \\
Asam format $(\mathrm{HCOOH})$ & 91,69 & 98,76 & 106,77 & 117,87 \\
Asam asetat $\left(\mathrm{CH}_{3} \mathrm{COOH}\right)$ & 191,01 & 88,09 & 302,74 & 280,98 \\
Asam propionat $\left(\mathrm{CH}_{3} \mathrm{CH}{ }_{2} \mathrm{COOH}\right)$ & 183,73 & 99,53 & 77,18 & 83,65 \\
Asam valerat & 110,70 & 236,05 & 165,01 & 183,16 \\
$\left(\mathrm{CH}_{3} \mathrm{CH}_{2} \mathrm{CH}_{2} \mathrm{CH}_{2} \mathrm{COOH}\right)$ & & & & \\
Etanol $\left(\mathrm{CH}_{2} \mathrm{CH}_{2} \mathrm{OH}\right)$ & 24,03 & 23,12 & 34,11 & 29,1 \\
Propanol $\left(\mathrm{CH}_{3} \mathrm{CH}_{2} \mathrm{CH}_{2} \mathrm{OH}\right)$ & 59,72 & 74,08 & 72,09 & 40,65 \\
pH & 5,78 & 5,17 & 5,92 & 5,78 \\
\hline
\end{tabular}

lebih cenderung teroksidasi yang ditandai dengan peningkatan asetat yang dihasilkan (Gambar 4(c)). S. cerevisiae juga mengonsumsi etanol pada kondisi glukosa menurun dan atau dikonsumsi bersama dengan glukosa (Raamsdonk dkk., 2001). Hasil penelitian menunjukkan pengendalian $\mathrm{pH}$ baik pada reaktor bakteri maupun ragi tidak dapat meningkatkan pembentukan etanol, namun mempengaruhi konsentrasi komposisi asam volatil (Tabel 1). Pada reaktor bakteri dan ragi, pengendalian $\mathrm{pH}$ menghambat pembentukan asam laktat, propionat dan valerat serta peningkatan pembentukan asetat dan etanol.

Data hasil pembentukan produk fermentasi disajikan pada Tabel 2. Berdasarkan analisis neraca massa (Gambar 5), pada R1, persentase COD terlarut yang terkonversi menjadi turunan langsung asam piruvat sebesar $37,11 \%$, terdiri dari laktat, propionat, valerat dan propanol berurutan sebesar 17,$81 ; 8,00 ; 6,51 ;$ dan $4,80 \%$ dan turunan asetilKoA sebesar 7,34 \% yang terdiri dari format, asetat dan etanol berurutan sebesar 0,92; 5,89 dan 1,45\%. Pada R2, produk turunan asam piruvat yang terbentuk sebesar $54,07 \%$, terdiri dari laktat, propionat, valerat dan propanol berurutan sebesar 29,$37 ; 4,59 ; 14,69$; dan $5,43 \%$ dan produk turunan asetil-KoA sebesar $4,35 \%$ yang terdiri dari asetat dan etanol berurutan sebesar 2,88 dan 1,47\%.

Sementara itu, pada R3, pembentukan produk turunan asam piruvat sebesar $36,41 \%$ COD terlarut influen yang terdiri dari laktat, propionat, valerat dan propanol berurutan sebesar 28,98; 2,99; 8,64 dan $4,44 \%$ dan produk turunan asetil-KoA sebesar $18,78 \%$ terdiri dari format, asetat dan etanol berurutan sebesar 0,96; 8,31 dan 1,83\%. Pada R4, produk turunan piruvat sebesar 28,91 terdiri dari laktat, propionat, valerat dan propanol berurutan sebesar 24,$84 ; 3,08 ; 9,11$ dan $0,99 \%$ dan turunan asetil-KoA sebesar $17,92 \%$ yang terdiri dari format, asetat dan etanol berurutan sebesar 2,87; 7,33 dan $1,49 \%$. 


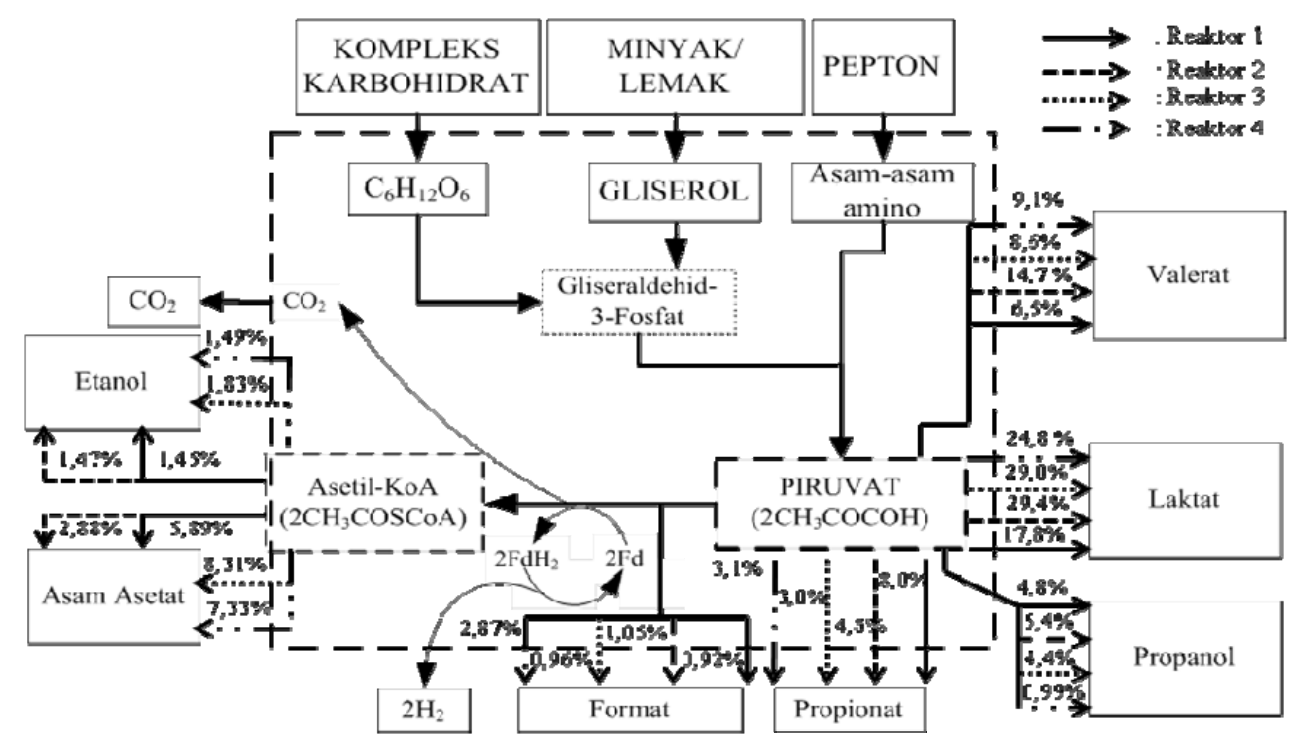

Gambar 5. Neraca masa pembentukan produk asidogenesa saat etanol tertinggi.

Tabel 2. Rekapitulasi hasil pembentukan produk fermentasi.

\begin{tabular}{ccccc}
\hline Reaktor & Produk piruvat (\%) & Produk asetil-KoA (\%) & Produk terukur (\%) & Produk tidak terukur (\%) \\
\hline R1 & 37,11 & 7,34 & 44,45 & 55,55 \\
R2 & 54,07 & 4,35 & 58,43 & 41,57 \\
R3 & 36,41 & 18,78 & 55,19 & 44,81 \\
R4 & 28,91 & 17,92 & 46,83 & 53,17 \\
\hline
\end{tabular}

Hasil penelitian menunjukkan pengendalian $\mathrm{pH}$ baik pada reaktor bakteri maupun reaktor ragi dapat menggeser jalur degradasi subtrat ke arah pembentukan produk asetil-KoA yang ditandai dengan peningkatan pembentukan produk asetilKoA dari $4,35 \%$ menjadi $7,34 \%$ pada reaktor bakteri dan dari $17,92 \%$ menjadi $18,78 \%$ pada reaktor ragi. Hal ini dapat disebabkan karena terjadi peningkatan asetat yang dihasilkan, sedangkan pembentukan etanol tidak terpengaruh. Rose dkk. (1954) menyatakan aktivitas enzim asetat kinase (AK) mengalami peningkatan pada seiring peningkatan $\mathrm{pH}$ dari 5,5-7,4 dan optimal pada $\mathrm{pH}$ 7,4. Pada penelitian ini, reaktor dengan pengendalian $\mathrm{pH}$ berada dalam rentang 6-6,5 dan mendekati $\mathrm{pH}$ optimal enzim AK. Sementara itu, nilai $\mathrm{pH}$ pada reaktor tanpa pengendalian $\mathrm{pH}$ berada dalam rentang $\mathrm{pH} 5,13-5,36$ untuk reaktor bakteri dan 5,64-5,75 pada reaktor ragi.

\section{Pengaruh Pengendalian pH terhadap Distribusi Pembentukan Produk Asidogenesa}

Berdasarkan hasil penelitian yang disajikan pada Gambar 6, diketahui pola penurunan $\mathrm{pH}$, pembentukan produk fermentasi reaktor bakteri dan ragi baik dengan maupun tanpa pengendalian $\mathrm{pH}$. Etanol tertinggi pada R1 terbentuk pada jam ke-60 sebesar 24,03 $\mathrm{mg} / \mathrm{L}$ dengan laju produksi 0,12 $\mathrm{mg} / \mathrm{L} / \mathrm{jam}$ dan sebesar 23,12 $\mathrm{mg} / \mathrm{L}, \quad$ laju pembentukan $0,10 \mathrm{mg} / \mathrm{L} /$ jam pada jam ke-72 $\mathrm{R} 2$.
Produksi etanol kedua reaktor bakteri tidak jauh berbeda menunjukkan pembentukan etanol tidak dipengaruhi oleh pengaturan $\mathrm{pH}$ reaktor. Pengaruh rentang $\mathrm{pH}$ terhadap perubahan pembentukan produk utama fermentasi dapat disebabkan karena perubahan metabolisme populasi yang sama atau perubahan populasi itu sendiri atau dapat juga gabungan kedua faktor tersebut ( $\mathrm{Yu}$ dan Fang, 2002). Pengendalian $\mathrm{pH}$ dalam rentang 6-6,5 dalam penelitian ini tidak menjadi faktor utama dalam pembentukan etanol namun lebih mempengaruhi konsentrasi asam lemak volatil yang dihasilkan.

Peningkatan konsentrasi asam asetat pada R1 terjadi seiring dengan waktu reaksi yang diikuti penurunan konsentrasi format, propionat, valerat dan etanol dari jam ke-12 hingga 48 percobaan. Produksi asetat tertinggi terjadi pada jam ke-72 dengan konsentrasi 338,57 mg/L, pH 5,95 dan laju produksi 4,70 mg/L/jam. Pada R2, pembentukan asetat terhambat dengan produksi tertinggi pada jam ke-72 sebesar 88,09 mg/L, pH 5,17 dan laju pembentukan $1,16 \mathrm{mg} / \mathrm{L} / \mathrm{jam}$. Pengaturan $\mathrm{pH}$ ke dalam rentang 6-6,5 pada penelitian ini dapat meningkatkan produksi asetat dan masuk dalam rentang $\mathrm{pH}$ optimal pembentukan asam asetat dari substrat glukosa (Fang dan Liu, 2002; Temudo dkk., 2007; Ren dkk., 2007; Syafila, 1993) dan gelatin (Yu dan Fang, 2003).

Kondisi $\mathrm{pH}$ pada R1 turun drastis mencapai $5,14 \pm 0,1$ pada 24 jam pertama penelitian dan 

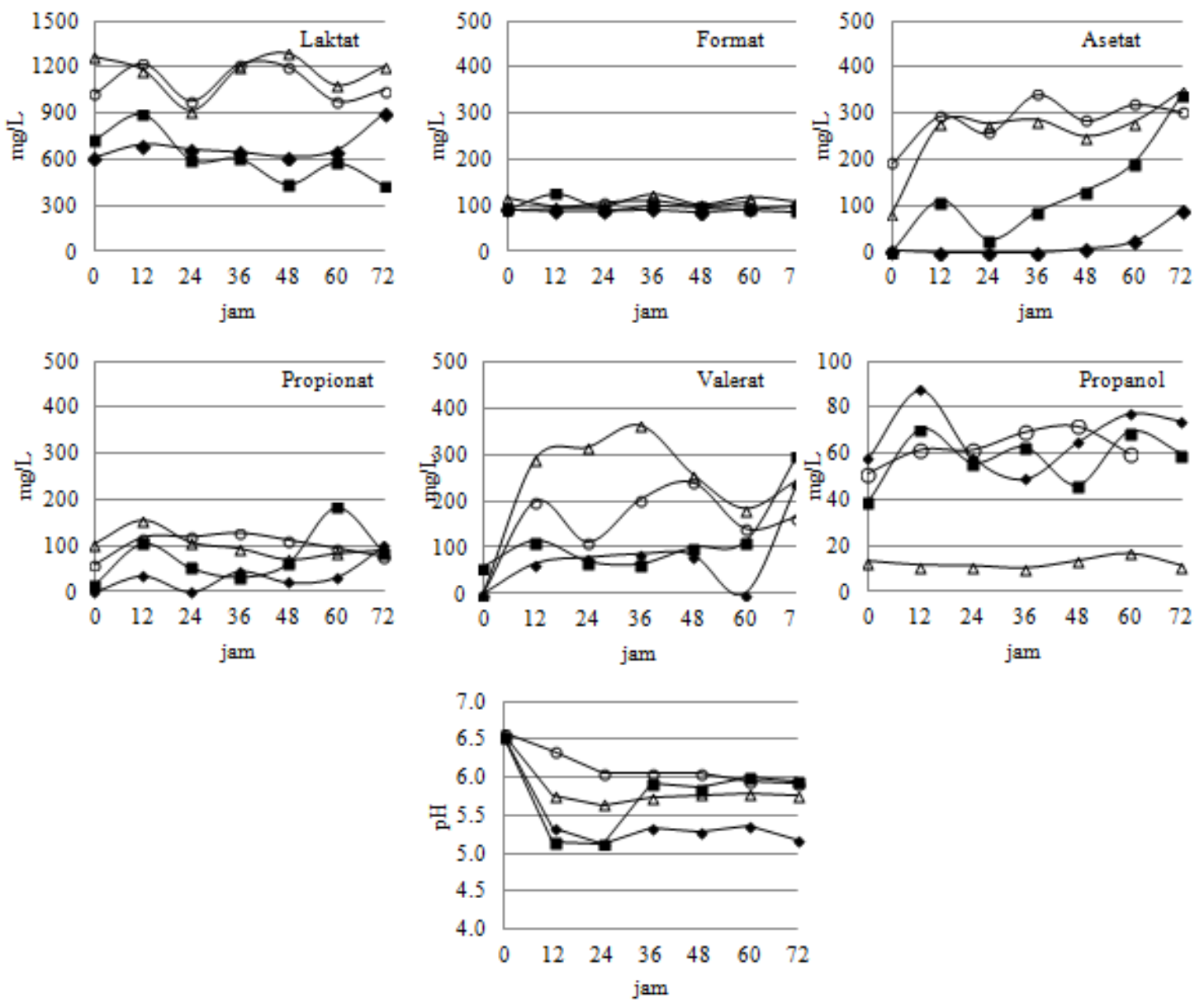

Gambar 6. Profil pembentukan produk asidogenesa pada reaktor bakteri dan reaktor S. cerevisiae. Arti tanda $\dashv-\mathrm{R} 1 ; \multimap \mathrm{R} 2 ; \bigcirc: \mathrm{R} 3$ dan $\triangle \mathrm{R} 4$.

setelah itu penurunan $\mathrm{pH}$ yang terjadi sangat kecil dengan nilai $\mathrm{pH}$ dalam kisaran 5,88 $\pm 0,6$. Penurunan $\mathrm{pH}$ di awal fermentasi asidogenesa menyebabkan pembentukan asam propionat dalam jumlah yang besar dan optimal terbentuk pada $\mathrm{pH}$ 4-5,5 (Wang dkk., 2006a; Wang dkk., 2006b; Yu dan Fang, 2003). Namun pada penelitian ini, pengaturan $\mathrm{pH}$ dalam rentang 6-6,5 menghasilkan propionat lebih besar dari pada reaktor tanpa pengendalian $\mathrm{pH}$. Propionat tertinggi pada reaktor anaerob dengan pengendalian $\mathrm{pH}$ terbentuk pada jam ke-60 sebesar $183,73 \mathrm{mg} / \mathrm{L}, \mathrm{pH}$ 6,01 dan laju produksi 0,96 $\mathrm{mg} / \mathrm{L} / \mathrm{jam}$. Sedangkan pada R2, produksi tertinggi terjadi pada jam ke-72 sebesar 99,53 $\mathrm{mg} / \mathrm{L}$ dengan pH 5,17 dan laju produksi sebesar 1,38 mg/L/jam.

Asam propionat yang terbentuk selalu disertai asetat. Ren dkk (1997) dan Wang dkk (2006b) menyatakan dalam fermentasi anaerob yang berlangsung kontinyu, rasio NADH/NAD ${ }^{+}$di dalam sel harus dalam jumlah yang tepat dan propiogenesis dapat menghasilkan $\mathrm{NAD}^{+}$lebih banyak dibandingkan butirogenesis dalam proses anaerob. Dalam kondisi yield NADH tinggi, fermentasi asam propionat akan mengganti fermentasi asam butirat secara spontan untuk menjaga rasio $\mathrm{NADH} / \mathrm{NAD}^{+}$dalam jumlah yang tepat, khususnya pada $\mathrm{pH}$ 5-6.

Valerat tertinggi R1 terbentuk pada jam ke-72 sebesar 296,74 $\mathrm{mg} / \mathrm{L}$ dengan laju produksi 3,33 $\mathrm{mg} / \mathrm{L} / \mathrm{jam}$. Pada R2, produksi tertinggi terjadi pada jam ke-72 sebesar 236,05 mg/L dengan laju produksi 3,28 $\mathrm{mg} / \mathrm{L} / \mathrm{jam}$. Pembentukan asam valerat pada penelitian ini dipengaruhi oleh jenis sumber nitrogen yang digunakan. Asam valerat yang terbentuk pada reaktor anaerob tanpa dan dengan pengendalian $\mathrm{pH}$ diduga berasal dari degradasi asam amino (pepton) oleh bakteri penghasil propionat dan diperkuat dengan produk utama asidogenesa berupa asetat, propionat dan valerat. Degradasi asam amino oleh bakteri strain Propionibacterium freudenreichii mempengaruhi pembentukan valerat dengan peningkatan konsentrasi valerat 3-10 kali lebih besar dibandingkan dengan kontrol. Pembentukan valerat menggunakan jalur degradasi L-leucin menjadi asam $\alpha$-ketoisokaproat dengan bantuan asam $\alpha$ ketoglutarik (Thierry dkk., 2002; Thierry dkk., 2004). Selanjutnya ketokaproat didegradasi menjadi 
valeratdehide dan terdegradasi menjadi valerat dengan bantuan enzim aldehid dehidrogenase (Dhande dkk., 2012).

Pembentukan asam butirat tidak terjadi. Hal ini dapat disebabkan karena sumber biomassa yang digunakan pada penelitian ini berasal dari kolam pengolahan limbah cair industri minyak sawit dan rumen sapi yang memungkinkan untuk pertumbuhan bakteri anaerob fakultatif. Secara umum, asam butirat merupakan produk utama asidogenesa yang hanya dihasilkan oleh bakteri obligat anaerob seperti Butyribacterium methylotrophicum, Butyrivibrio fibrisolvens, Clostridium butyricum, C. kluyveri, C. pasteurianum, Eubacterium limosum, Fusobacterium nucleatum (Kim dan Gadd, 2006).

\section{Perbandingan Produksi Etanol dan Asam Volatil oleh Bakteri Kultur Campuran Anaerob dan $S$. cerevisiae}

Produksi etanol tertinggi pada R3 terbentuk pada jam ke-72 sebesar 34,11 mg/L dengan laju produksi $0,25 \mathrm{mg} / \mathrm{L} / \mathrm{jam}$. Pada $\mathrm{R} 4$, etanol tertinggi terbentuk pada jam ke-60 sebesar 29,17 mg/L dengan laju produksi $0,10 \mathrm{mg} / \mathrm{L} / \mathrm{jam}$. Efektivitas konversi COD terlarut menjadi etanol pada R3 sebesar $1,83 \%$ dan $1,49 \%$ pada R4 dan tergolong sangat kecil jika dibandingkan dengan substrat glukosa menurut reaksi:

$$
\mathrm{C}_{6} \mathrm{H}_{12} \mathrm{O}_{6} \rightarrow 2 \mathrm{C}_{2} \mathrm{H}_{5} \mathrm{OH}+2 \mathrm{CO}_{2}
$$

(Kosaric dan Sukan, 2001).

Produksi etanol oleh ragi dengan jalur konversi langsung asam piruvat menjadi asetaldehid menghasilkan etanol lebih tinggi dibandingan produksi etanol oleh bakteri anaerob yang menggunakan jalur konversi piruvat ke asetilCoA dan asetaldehid. Selain etanol, fermentasi ragi menghasilkan asam volatil asetat, propionat dan valerat. Karakteristik substrat akan mempengaruhi jenis produk samping yang terbentuk dari fermentasi asidogenesa oleh ragi. Degradasi glukosa oleh ragi akan menghasilkan produk samping berupa gliserol, asam asetat, suksinat dan laktat (Alfenore dkk., 2004; Thomas dkk., 1995; Oura, 1977). Produk samping tersebut juga terbentuk dari substrat selain glukosa seperti softwood (Söderström dkk., 2005; Talebnia dkk., 2005) dan tepung jagung (Lu dkk., 2003) yang disertai dengan pembentukan propionat, butirat dan valerat. Asam volatil rantai panjang seperti isovalerat, butanoat, oktanoat dan dekanoat juga dihasilkan oleh $S$. cerevesiae proses fermentasi pembuatan anggur (Vilanova dkk., 2012; Varela dkk., 2012; Sun dkk., 2011; Orte dkk., 2006).

Produksi asam asetat tertinggi R3 sebesar $340,50 \mathrm{mg} / \mathrm{L} / \mathrm{jam}$ dengan laju produksi 4,12 $\mathrm{mg} / \mathrm{L} / \mathrm{jam}$ dan 348,68 $\mathrm{mg} / \mathrm{L} / \mathrm{jam}$ dengan laju produksi $3,67 \mathrm{mg} / \mathrm{L} / \mathrm{jam}$ pada $\mathrm{R} 4$. Produksi propionat tertinggi sebesar $126,72 \mathrm{mg} / \mathrm{L} / \mathrm{jam}$, laju produksi 1,85 $\mathrm{mg} / \mathrm{L} /$ pada $\mathrm{R} 3$ dan 153,92 $\mathrm{mgCOD} / \mathrm{L}$, laju produksi $4,08 \mathrm{mg} / \mathrm{L} / \mathrm{jam}$ pada $\mathrm{R} 4$. Sedangkan untuk asam valerat, produksi tertinggi sebesar $240,02 \mathrm{mg} / \mathrm{L}$ dengan laju produksi 5,00 $\mathrm{mg} / \mathrm{L} / \mathrm{jam}$ pada R3 dan $362,88 \mathrm{mg} / \mathrm{L}$ dengan laju produksi $10,08 \mathrm{mg} / \mathrm{L} / \mathrm{jam}$ pada $\mathrm{R} 4$.

\section{KESIMPULAN}

Pengaturan $\mathrm{pH}$ pada reaktor bakteri dan ragi tidak efektif meningkatkan pembentukan etanol dan hanya mempengaruhi pembentukan asam-asam volatil. Diperlukan metoda lain untuk mengoptimalkan pergeseran jalur metabolisme bakteri kultur campuran anaerob ke arah pembentukan asetil-KoA dengan menekan pembentukan produk turunan piruvat seperti laktat, propionat dan valerat, sehingga dapat membantu peningkatan pembentukan etanol.

\section{UCAPAN TERIMAKASIH}

Penelitian ini didanai oleh Hibah Program Riset dan Inovasi Kelompok Keahlian ITB, No. Kontrak : FTSL. PN-6-03-2012, tahun 2012.

\section{DAFTAR PUSTAKA}

Ahmad, A., 2001. Biodegradasi Limbah Cair dalam Industri Minyak Sawit dalam Sistem Bioreaktor Anaerob. Disertasi, Program Doktor, Institut Teknologi Bandung. Bandung

Ahmad, A.L, Ismail, S., dan Bhatia, S., 2003. Water Recycling from Palm Oil Mill Effluent (POME) Using Membrane Technology. Desalination, 157:87-95.

Alfenore, S., Cameleyre, X., Benbadis, L., Bideaux, C., Uribelarrea, J.L., Goma, G., Molina-Jouve, C., dan Guillouet, S.E., 2004. Aeration strategy: A Need for Very High Ethanol Performance in Saccharomyces cerevisiae Fed-batch Process. Appl Microbiol Biotechnol, 63:537-542.

Andrio, D., Handajani, M., dan Syafila, M., 2012. The Potential of Ethanol Production from High Strength Organic Wastewater on Acidogenic Phase : A Preliminary Study. The $5^{\text {th }}$ AUN/SEED-Net Regional Conference on Global Environment, Bandung, November $21^{\text {st }}-22^{\text {nd }} 2012$.

Anonim, 2011. Indonesian Palm Oil Exports Surge by 8,9 Percent in H1. Website : http://www.gapki.or.id/news/detail/269/Indone 
sian-Palm-Oil-Exports-Surge-by-8.9-Percentin-H1. Diunduh 12 September 2011.

Ardhana, M.M., dan Fleet, G.H., 2003. The Microbial Ecology of Cocoa Bean Fermentations in Indonesia. International Journal of Food Microbiology, 86:87-99.

Bengtsson, S., Hallquist, J., Werker, A., dan Welander, T., 2008. Acidogenic Fermentation of Industrial Wastewaters: Effects of Chemostat Retention Time and $\mathrm{pH}$ on Volatile Fatty Acids Production. Biochemical Engineering Journal, 40:492-499.

Chotineeranat, S., Wansuksri, R., Piyachomkwan, K., Chatakanonda, P., Weerathaworn, P., dan Sriroth, K., 2010. Effect of Calcium Ions on Ethanol Production from Molasses by Saccharomyces Cerevisiae. Sugar Technology 12(2):120-124.

de Sa, L.R.V., de Oliveira, M.A.L., Cammarota, M.C., Matos, A., dan Ferreira-Leitao, V.S., 2011. Simultaneous Analysis of Carbohydrates and Volatile Fatty Acids by HPLC for Monitoring Fermentative Biohydrogen Production. International Journal of Hydrogen Energy, 36:15177-15186.

Dhande, Y.K., Xiong, M., dan Zhang, K., 2012. Production of C5 Carboxylic Acids in Engineered Escherichia coli. Process Biochemistry, 47:1965-1971.

Dillon, H.S., Laan, T., dan Dillon, H.S., 2008. Biofuels - at What Cost ?: Government Support for Ethanol and Biodiesel in Indonesia. One of A Series of Reports Addressing Subsidies for Biofuels in Developing Countries. Prepared for : The Global Subsidies Initiative (GSI) of the International Institute for Sustainable Development (IISD) Geneva, Switzerland. 2835.

Demirbas, A., 2005. Bioethanol from Cellulosic Materials: A Renewable Motor Fuel from Biomass. Energy Sources, 27:327-337.

Fang, H.H.P., dan Liu, H., 2002. Effect of pH on Hydrogen Production from Glukosa by a Mixed Culture. Bioresource Technology, 82:87-93.

Grady, L.C.P.Jr., Daigger, G.T., dan Lim, H.C., 1999. Biological Wastewater Treatment, $2^{\text {nd }}$ Edition. Marcel Dekker, New York. p32.

Han, S.K., Kim. H.S., Sung, S., dan Shin, H.S., 2003. Effect of pH and Repeated Heat-Shock Treatment on Hydrogen Fermentation of Sucrose by a Mixed Culture. Env. Eng. Res. Korean Society of Environmental Engineers. 8(4):202-211.
Hernandez-Orte, P., Bely, M., Cacho, J., dan Ferreira, V., 2006. Impact of Ammonium Additions on Volatile Acidity, Ethanol, and Aromatic Compound Production by Different Saccharomyces cerevisiae Strains during Fermentation in Controlled Synthetic Media. Australian Journal of Grape and Wine Research 12:150-160.

Kim, B.H., dan Gadd, G.M., 2008. Bacterial Physiology and Metabolism. Cambridge University Press, Cambridge. p252-289.

Kosaric, N., dan Sukan, F.V., 2001. The Biotechnology of Ethanol : Classical and Future Applications, Part II. Potential Source of Energy. WILEY-VCH Verlag $\mathrm{GmbH}$, Weinheim, 89-181.

Lewis, R.S., Datar, R.P., dan Huhnke, R., 2005. Biomass to Ethanol. Encyclopedia of Chemical Processing, 1(1):143-51.

Lin, Y.H., Chien, W.S., Duan, K.J., dan Chang, P.R., 2011. Short Communication : Effect of Aeration Timing and Interval During VeryHigh-Gravity Ethanol Fermentation. Process Biochemistry, 46:1025-1028.

Lu, X., Li, Y., Duan, Y., Shi, Z., dan Mao, Z., 2003. A Novel, Repeated Fed-Batch, Ethanol Production System with Extremely Long Term Stability Achieved by Fully Recycling Fermented Supernatants, Biotechnology Letters, 25:1819-1826.

Mohammadi, M., Man, H.C., Hassan, M.A., dan Yee, P.L., 2010. Review : Treatment of Wastewater from Rubber Industry in Malaysia. African Journal of Biotechnology, 9(38):62336243.

Murdiyatmo, U., 2006. Pengembangan Industri Etanol : Prospek, Kendala dan Tantangan. Workshop Nasional Bisnis Biodiesel dan Bioetanol di Indonesia. Jakarta, 21 November, 80-86.

Oura, E., 1977. Reaction Products of Yeast Fermentation. Process Biochem. 12(3):19.

Poh, P.E., dan Chong, M.F., 2009. Review : Development of Anaerobic Digestion Methods for Palm Oil Mill Effluent (POME) Treatment. Bioresource Technology, 100:1-9.

Raamsdonk, L.M., Diderich, J.A., Kuiper A., van Gaalen, M., dan Kruckberg, A.L., 2001. Coconsumption of Sugars or Ethanol and Glucose in a Saccharomyces cerevisiae Strain Deleted in the HXK2. Yeast, 18:1023-1033.

Ren, N.Q., Wang, B., dan Huang, J.C., 1997. Ethanol-Type Fermentation from Carbohydrate in High Rate Acidogenic Reactor. Biotechnology and Bioengineering, 54(5):428-433. 
Ren, N.Q., Chua, H., Chan, S.Y., Tsang, Y.F., Wang, Y.J., dan Sin, N., 2006. Assessing Optimal Fermentation Type for Bio-hydrogen Production in Continuous-Flow Acidogenic Reactors. Bioresource Technology, 98(9): 1774-1780 .

Ren, N.Q., Xing, D., Rittmann, B.E., Zhao, L., Xie, T., dan Zhao, X., 2007. Microbial Community Structure of Ethanol Type Fermentation in Bio-hydrogen Production. Environmental Microbiology, 9(5):1112-1125.

Rose, L.A., Grunberg-Manago, M., Korey, R.S., dan Ochoa, S., 1954. Enzymatic Phosphorylation of Acetate. Journal Biol. Chem., 211:737-756.

Shen, Y., Ge, X.M., dan Bai, F.W., 2010. Application of Oscillation for Efficiency Improvement of Continuous Ethanol Fermentation with Saccharomyces Cerevisiae under Very-High-Gravity Conditions. Appl. Microbiol. Biotechnol., 86:103-108.

Söderström, J., Galbe, M., dan Zacchi, G., 2005. Separate Versus Simultaneous Saccharification and Fermentation of Two-Step Steam Pretreated Softwood for Ethanol Production. Journal of Wood Chemistry and Technology, 25(3):187-202.

Sun, S.Y., Jiang, W.G., dan Zhao, Y.P., 2011. Evaluation of Different Saccharomyces cerevisiae Strains on the Profile of Volatile Compounds and Polyphenols in Cherry Wines. Food Chemistry, 127:547-555.

Syafila, M., 1993. Anaerobic Degradation of Glucose of Acidogenic Phase in Circulating Bed Reactor (CBR). Jurnal Teknik Lingkungan, 2(1):12-20.

Syafila, M., Wisjnuprapto, dan Susanti, S., 1998. The Influence of Hydrogen Concentration on End Product Formation in Acidogenic Phase of Anaerobic Treatment of Palm Oil Mill Effluent Using Circulating Bed Reactor. Prosiding ITB, 30(1):17-20.

Syafila, M., Handajani, M., dan Prayascitra, A., 2010. The Effect of Nitrogen Gas Flushing on Intermediate Products Formation in Acidogenic Stage of Anaerobic Process of Cocoa Sweatings. Institut Teknologi Bandung Journal of Engineering Science, 42(2):129136.

Talebnia, F., Niklasson, C., and Taherzadeh, M.J., 2005. Ethanol Production from Glucose and Dilute-Acid Hydrolyzates by Encapsulated $S$. Cerevisiae. Biotechnology and Bioengineering, 90(3):345-353.

Tang, Y., Shigematsu, T., Morimura, S., and Kida, K., 2005. Microbial Community Analysis of
Meshophilic ananerobic Protein Degradation Process Using Bovine Serum Albumin (BSA)Fed Continuous Cultivation. Journal of Bioscience and Bioengineeering, 99(2):150164.

Temudo, M.F., Kleerebezem, R., dan van Loosdrecht, M., 2007. Influence of the $\mathrm{pH}$ on (Open) Mixed Culture Fermentation of Glucose: A Chemostat Study. Biotechnology and Bioengineering, 1(98):69-79.

Temudo, M.F., Poldermans, R., Kleerebezem, R., dan van Loosdrecht, M.C.M., 2008. Glycerol Fermentation by (Open) Mixed Cultures: A Chemostat Study. Biotechnology and Bioengineering, 100(6):1088-1098.

Tekasakul, P., dan Tekasakul, S., 2006. Environmental Problem Related to Natural Rubber Production in Thailand. Journal Aerosol Resource, 21(2):122-129.

Thierry, A., Maillard, M.B., dan Yvon, M., 2002. Conversion of L-Leucine to Isovaleric Acid by Propionibacterium freudenreichii TL 34 and ITGP23. Applied and Environmental Microbiology, 2:608-615.

Thierry, A., Richoux, R., dan Kerjean, R.R., 2004. Isovaleric Acid is Mainly Produced by Propionibacterium freudenreichii in Swiss Cheese, International Dairy Journal, 14:801807.

Thomas, K.C., Hynes, S.H., dan Ingledew, W.M., 1996. Practical and Theoretical Considerations in the Production of High Concentrations of Alcohol by Fermentation. Process Biochem., 31:321-331.

Van Haandel, A., and Van Der Lubble, J., 2012. Handbook of Biological Wastewater Treatment Design and Optimation of Activated Sludge, IWA Publishing, London. pp 8-10.

Varela, C., Torrea, D., Schmidt, S.A., AncinAzpilicueta, C., dan Henschke, P.A., 2012. Effect of Oxygen and Lipid Supplementation on the Volatile Composition of Chemically Defined Medium and Chardonnay Wine Fermented with Saccharomyces cerevisiae. Food Chemistry, 135:2863-2871.

Vilanova, M., Siebert, T.E., Varela, C., Pretorius, I.S., dan Henschke, P.A., 2012., Effect of Ammonium Nitrogen Supplementation of Grape Juice on Wine Volatiles and Vonvolatiles Composition of the Aromatic Grape Variety Albariño. Food Chemistry, 133:124131.

Wang, L., Zhou, Q.,. dan Zheng, G.H., 2006 . Comprehensive Analysis of the Factors for Propionic Acid Accumulation in Acidogenic 
Phase of Anaerobic Process. Environmental Technology, 27(3):269-276.

Wang, L., Zhou, Q., dan Li, F.T. 2006 . Avoiding Propionic Acid Accumulation in the Anaerobic Process for Biohydrogen Production. Biomass and Bioenergy, 30:177-182.

Wu, K.J., Chang, C.F., dan Chang, J.S., 2007. Simultaneous Production of Biohydrogen and Bioethanol with Fluidized-Bed and PackedBed Bioreactors Containing Immobilized Anaerobic Sludge. Process Biochemistry, 42:1165-1171.

Zhao, X.Q., Xue, C., Ge, X.M., Yuan, W.J. Wang, J.Y., dan Bai, F.W., 2009. Impact of Zinc Supplementation on the Improvement of Ethanol Tolerance and Yield of Selfflocculating Yeast in Continuous Ethanol Fermentation. Journal of Biotechnology, 139:55-60.
Zhu, Y., dan Yang, S.T., 2005. Effect of $\mathrm{pH}$ on Metabolic Pathway Shift in Fermentation of Xylose by Clostridium tyrobutyricum. Journal of Biotechnology, 110:143-157.

Yamashita, Y., Kurosumi, A., Sasaki, C., dan Nakamura, Y., 2008. Ethanol Production from Paper Sludge by Immobilized Zymomonas mobilis. Biochemical Engineering Journal, 42:314-319.

Yenigün, O., Kizilgün, F., dan Yilmazer, G., 1996. Inhibition Effects of Zinc and Copper on Volatile Fatty Acid Production During Anaerobic Digestion. Environmental Technology, 17(11):1269-1274.

Yu, H.Q., dan Fang, H.H.P., 2003. Acidogenesis of Gelatin-rich Wastewater in an Upflow Anaerobic Reactor: Influence of $\mathrm{pH}$ and Temperature. Water Research, (37):55-66. 